\title{
Study on the Problems Existing in the Employment Education for College Students in China's Independent Colleges and Corresponding Countermeasures
}

\author{
Dajiang Wang, Qixin Zhu, Yin Lin \\ Oujiang College, Wenzhou University, Wenzhou, China \\ Email: 21298154@qq.com
}

Received May $10^{\text {th }}$, 2013; revised June $11^{\text {th }}$, 2013; accepted June $18^{\text {th }}$, 2013

\begin{abstract}
Copyright (c) 2013 Dajiang Wang et al. This is an open access article distributed under the Creative Commons Attribution License, which permits unrestricted use, distribution, and reproduction in any medium, provided the original work is properly cited.
\end{abstract}

\begin{abstract}
In the face of the increasingly severe employment situation, the role of employment education of independent colleges is becoming more and more important in solving students' employment problems. During the development process, however, the current employment education for students in independent colleges is still imperfect in five aspects: The understanding of the concept of employment education is inadequate, the courses set for employment education is not sufficient, the team construction for employment education is not enough, the objects of employment education are not fully motivated, and the environment of employment education is not well created. This situation requires independent colleges to proceed from their actual situation and actively take efficient countermeasures, so as to further improve the effectiveness of the employment education for students in independent colleges.
\end{abstract}

Keywords: Independent Colleges; Employment Education; Problems; Countermeasures

\section{Introduction}

In 2011, Notice of the State Council on Doing Well in Work of University Graduates' Employment was issued and clearly points out that “a better work of university graduates' employment is an important measure to promote economic development and social harmony” (State Council No 16, 2011). Independent colleges, as important components of China's higher education system, are playing a noticeable role in both cultivating the talents and solving the problem of graduates' employment. Facing the severe situation, employment education carried out by independent colleges can be an efficient way to relieve employment pressure and to solve this problem, which also has great significance for the developments of independent colleges themselves.

\section{Necessity of the Employment Education for Students in Independent Colleges}

As important components of Chinese higher education system, independent colleges have their development history far shorter than that of regular institutions of higher education and are still not highly recognized in the society, which makes employment problems even more serious for their students. Employment education for students is an efficient way to fix the employment problem. Therefore, it appears to be particularly necessary for independent colleges to carry out the employment education for their students

1. To adapt to the development of real society

"Fund project: Scientific Research Project, Department of Education, Zhejiang province (Y201226256).
With rapid development in the real society, the requirements for talents raised by employing units are becoming higher and higher. Influenced by the traditional concept of talents in the society, employing units often proceed from the "education background" when they select talents and habitually recruit talents from some famous schools or those colleges and universities they trust or have close relations with. At the same time, independent colleges were established not long ago and have limited social influence, and the quality of their graduates has not been checked and recognized by the society. For these reasons, students graduating from independent colleges are often in a disadvantageous position in the fierce talent competition at the moment, which leaves a severer employment situation for students in independent colleges. Employment education carried out in an independent college is aimed to cultivate students' lifelong survival ability and quality, which is of great significance for improving students' ability to choose a job, and which is also a measure necessary to actively adapt to the development of real society.

2. To meet the development of independent colleges themselves

Facing the increasingly severer employment situation, institutions of higher education are paying more and more attention to the vocational guidance work for their graduates. However, such guidance work in most institutions only stays at the surface or is confined to the guidance for a certain employment stage, which makes the employment education narrow in objective with no systematicness and perspectiveness. Besides, the content of employment education is monotonous and inflexible. The vocational guidance is not scientific and systematic, unable 
to guide students according to their personal characteristics. These problems also exist in independent colleges and are even more serious in some aspects. Therefore, independent colleges should adopt good points and avoid shortcomings when carrying out the employment education and guide students according to their actual situation to give full play to their characteristics, thus promoting the colleges forwards a higher level of development.

3. To meet the employment development of students in the future

Students in independent colleges are mostly contradictory combinations, which are manifested in the fact that they don't have solid academic basis, but, most of them have strong points, extensive hobbies and active minds. They don't have high targets but have strong practical abilities. Because of these characteristics, some students in independent colleges mentally have a kind of misunderstanding. On the one hand, "they don't think they are winners of the National Matriculation Test, which left them with more disappointment and helplessness when compared to those who had entered in regular universities" (Zhang Liang, 2012), which is the cause that they would loss confidence when facing the employment competition. On the other hand, some students' expectation for employment is too high because they have paid expensive tuition fees and they expect more in return. Some students even pin their hope on their rich and superior family conditions and make no basic preparation for their employment. As a result, the comprehensive quality and ability of students in independent colleges are insufficient and their employment competitiveness is not strong. That independent colleges carry out effective employment education for students according to students' characteristics plays an important role in promoting students' comprehensive quality and ability and is an important means of improving students' employment competitiveness.

\section{Problems Existing in the Process of Employment Education for Students in Independent Colleges}

In recent years, the employment education for students has already being a common view in numerous institutions of higher education, and independent colleges even consider it as an important means of improving students' comprehensive quality and ability, cultivating students' ability to adapt to the requirements of real society, and mitigating their employment pressure. Nonetheless, the employment education for students in independent colleges is still at the development stage and there are still some problems in the process, which would have negative impacts on the effectiveness of employment education.

1 . The understanding of the concept of employment education is inadequate.

Compared with state-run schools, independent colleges have fewer state funds. Besides, the different student recruitment situations of independent colleges also lead to the situation where they have different understanding of and attach different level of importance to the employment guidance courses for students. The employment education is simply understood as the education of employment skills and the cultivation of students' employment and career consciousness as well as the education of professional ethics and professional ideals are overlooked. The inadequate understanding of the concept of employment education makes most employment education work stay at the surface and the employment education for college students also basically stays at the guidance on the skills of choosing a job. Consequently, many students come to know that they still have a lot of knowledge and abilities to learn when they are graduating, which also directly increases the difficulty of their employment. For example, Luo Zhuhua et al. took 542 juniors of an independent college of Hunan Province as the test samples for investigating the "time statistics of career planning". The results show that " $29.52 \%$ of the samples begin their career planning till the third year of their college lives, and another 28.04\% have still not start the career planning up to this investigation” (Luo Zhuhua \& Chen Xi, 2010)

2. The courses set for employment education is not sufficient.

Due to the limited understanding of employment education, independent colleges are not scientific when setting employment education courses. This is mainly manifested in the following aspects. Firstly, most schools do not set employment education courses continuously and only incorporate employment education into the courses for graduates. In these courses, teachers simply introduce some employment skills to students, which cannot basically improve students' employment ability. Secondly, the special identity of independent colleges makes them dependent on the teaching resources of their Alma Mater when carrying out the employment education. Especially in the setting of teaching courses, independent colleges completely copy their Alma Mater's setting of majors. Their courses are single and there are no brand majors that conform to their own conditions. At last, the unscientific setting of employment education courses and the insufficient understanding directly result in the excessively abstract positioning of teaching objectives, which cannot guide the actual problems relating to employment and cannot offer help for graduates in terms of employment skills.

3. The team construction for employment education is not enough.

The key to guarantee the effectiveness of employment education of an independent college lies in the quality of the teaching staff of employment education. Therefore, it is particularly important to cultivate a contingent of teaching staff who are adept at professional knowledge, steadfast in mind, upright in daily behavior and rich in employment practice. This is the new requirement for the quality of employment education teachers raised by independent colleges under the new situation, and is also required to further promote the employment education progress and the development of the colleges themselves. However, the current situation shows that, a large part of teachers of many independent colleges are employed form senior universities, and the smart part is introduced from other place. Yet, most of the introduced teachers are young and lack of teaching experience and scientific research ability (Xu Huimin \& Chen Feng, 2012). Meanwhile, teachers are not willing to volunteer to participate in practical education, which severely influences the effectiveness of employment education.

4. The environment of employment education is not well created.

The environment of employment education is also an important factor that influences the effectiveness of employment education. The environment of employment education mainly includes internal environment and external environment. Internal environment mainly means the school environment of employment education, namely how much attention school teachers and students pay to the employment education. At present, 
many independent colleges do not take employment education seriously and have not truly realized the important role of employment education in solving employment problems for college students. Consequently, independent colleges make no vigorous efforts to create a favorable environment for employment education, and their employment education is not continuous and expandable in both time and space. External environment mainly refers to the environment of employment education outside schools, namely how much the society or other schools advocate employment education. Since the employment education starts late in China and the employment education in independent colleges starts even later and is not fully developed, the social recognition of independent colleges is not high and the social environment of employment education is not so good.

5 . The objects of employment education are not fully motivated.

After going through the setback in the college entrance examination, some students in independent colleges are likely to be unconfident and often let things be without making any active efforts. This undisciplined and self-abased mentality gives rise to a series of bad consequences. At the same time, students in independent colleges usually have superior family conditions and strong self-awareness. When facing new things, they often proceed from their own standpoint or immediate interests, disdain the things not catering to their preferences and have no motivation to study. Besides, with the invisible increase in employment pressure and employment education teachers' inability to provide effective advice for the objects of employment education due to their own defects, some students gradually lose confidence and patience in employment education and become far less motivated in learning.

\section{Countermeasures for the Future Development of Employment Education for Students in Independent Colleges}

At present, employment education carried out in colleges has become a new option for solving such problems for students. Nonetheless, the effect of such employment education in independent colleges is often less than satisfactory. Therefore, as to the above-mentioned problems existing in independent colleges' employment education, it is particularly important for independent colleges to actively explore some effective measures that are favorable for the development of employment education in future.

\section{Build up a correct concept of employment education}

Employment education is an integral part of college education and runs through the whole process of college education. Setting up a correct concept of employment education is a requirement not only for employment education teachers, but also for the objects of employment education. The correct concept of employment education requires teachers to change their narrow concept, fully realize the important role of employment education in the education for students, and strengthen students' comprehensive quality. This is manifested not only in the teaching of employment skills, but more in the cultivation of students' employment consciousness and entrepreneurship and the increase in the education of career planning, professional ethics and professional ideals as well as professional laws and regulations for students, enabling students to master more comprehensive and practical survival and creation abilities regarding employment. Meanwhile, it also requires the objects of employment education to pay full attention to employment, constantly improve their own comprehensive quality in the process, and thus increase their social competitiveness.

2. Improve the scientificity and standardization of employment education courses

The ineffective employment education in many independent colleges at present is largely caused by the unscientific setting of employment education courses. Employment education should start when students get enrolled in colleges rather than when they are graduating so that students can truly realize how to plan their future and fight for their targets in college years. Therefore, employment education courses should "improve employment guidance mode and employment education system" (Li Ming, 2012), and shall should be continuous and systematic. Students should receive the courses as early as they enter colleges. The law of physical and mental development of students should be taken into consideration when employment education courses are set so as to make students truly figure out the essence of employment education and thus lay a solid foundation for future employment. In addition, course setting should also reflect hierarchy and brand. Although the employment education starts late in China, its development speed is fast. If with no features in course arrangement, it is impossible to develop brand majors conforming to the development of independent colleges. Only by creating characteristic brand courses can independent colleges occupy an advantageous position in the fierce competition. At the same time, independent colleges also need to make innovations to the talent cultivation mode of employment education and make the target positioning for employment education in conformity with actual requirements.

3. Strengthen the teaching staff construction for employment education

Employment education is an important component of school education, in which process teachers play a vital role. As to the teaching staff, independent colleges should correctly handle the recruitment, training and management of teachers according to their own conditions. On the one hand, independent colleges should increase the recruitment standards of teachers, formulate a complete examination and evaluation system, set up a reasonable incentive mechanism and motivate teachers' work enthusiasm by approving and rewarding excellent teachers for their work, and encourage teachers to take an active part in social practice and continuously accumulate practical experience. On the other hand, schools should strengthen the cultivation and management of employment education teachers, provide intensive training for teachers on a regular basis, invite or employ excellent teachers from other schools to give lectures to constantly improve teachers' learning ability, and systematically assign teachers to study in appropriate enterprises and realize the school-enterprise cooperation to create a good external network for students' employment.

4. Create a favorable social employment atmosphere

Due to the increasingly severer employment situation, the employment pressure faced by graduates is also on the increase. Nowadays, many college graduates are feeling confused, lost or fear at their graduation. Therefore, independent colleges need to carry out mental health education together with employment education. Creating a favorable employment atmosphere for students requires schools to pay close attention to social employment trends and strengthen the publicity of employment information. Meanwhile, independent colleges should help graduates establish a correct employment attitude as soon as possible, 
foster the awareness of fair competition, and constantly improve their ability to meet challenges.

5. Integrate employment education and entrepreneurship education

Now, to be self-employed becomes a new way for many graduates to solve their employment problems. The Party Central Committee has also introduced policies to encourage college students to start their own business to promote the employment. Therefore, when independent colleges carry out the employment education, it is necessary to integrate it with entrepreneurship education to change students' employment idea. In the process of carrying out employment education, independent colleges should consciously impart knowledge regarding entrepreneurship to students and organize various activities like social practice, discipline competition, business plan competition, students' scientific research and quality development training to create a campus culture with innovative and entrepreneurial atmosphere, in which students can cultivate the ability to make innovations and start a business, thus increasing their employment rate when they graduate. For instance, "Zhongyuan University of Technology is implementing the training mode containing three types of talents, as "learning-type, profession-type, self-employed-type”. It established, cooperated with TAOBAO Company, the first Taobao Lab among universities of Henan Province to satisfy the need of practical teaching reform. Some best lecturers of Taobao University are invited to teach knowledge about online shops. Meanwhile, students are encouraged to open online shops or start their own businesses, so as to cultivate excellent talents who do business on the internet.” (Guo Yahong, 2010).

6. Guide students to improve their quality comprehensively

In the fierce social competition, the quality of graduates themselves directly determines whether they can obtain a job successfully. Therefore, graduates on the point of stepping into society need to improve their comprehensive ability by various means when they are still at school, which is very important. Firstly, they should constantly improve their professional quality and select the appropriate major. Secondly, they should continuously enhance their psychological quality to have the courage to face any difficulties and setbacks. Thirdly, they should continuously improve their competencies to be able to work as well as make research. Fourthly, they should constantly promote their cooperation ability and understand the importance of teamwork, correctly handle interpersonal relationship, strengthen their accomplishment and expand their social circle. As an integral part of college education, employment education plays a leading role in improving the comprehensive quality of college students. It needs to emphasize the significance of students' comprehensive competitiveness all the time and create a dynamic environment for students to pursue comprehensive advancement.

\section{REFERENCES}

Guo, Y. H. (2010). Problems existing in the employment work in independent colleges in the new age. Journal of Xianning College, 9, 157-158.

Li, M. (2011). Simple analysis of the employment work for students in independent colleges. 4

Luo, Z. H., \& Chen, X. (2010). Investigation into the employment preparation of students in independent colleges. Theory and Practice of Contemporary Education, 1, 30-32.

Notice on Further Implementing the Employment Work for Graduates of Regular Institutions of Higher Education (State Council No. 16) (2011).

Xu, H. M., \& Chen, F. (2012). Study on the employment ability of students in independent colleges and countermeasures. Pioneering with Science \& Technology Monthly (4th ed.).

Zhang, L. (2012). Primary investigation into the employment predicament of rural students in independent colleges. The Science Education Article Collects, 4. 